\title{
The Impact of Tax Knowledge and Budget Spending Influence on Tax Compliance
}

\author{
Behnud Mir Djawadi * \\ University of Paderborn
}

\author{
René Fahr^ \\ University of Paderborn and IZA
}

\begin{abstract}
We investigate within a controlled laboratory setting of a hypothetical tax system how tax knowledge about public expenditures and influence on budget spending affects tax compliance. To clearly disentangle any effects from factors that are known to influence tax compliance from previous studies, we control for tax commitment, risk attitude, income and effort exerted to earn the income which the taxpayers report truthfully or underreport to the tax authority. Non-parametric statistical analyses as well as multivariate regressions provide clear evidence that tax compliance is higher in tax systems with low power of authorities when providing complete transparency on public expenditures and when taxpayers are given the possibility to decide on the use of their taxes. With a powerful tax authority in place which is reflected in high audit rates, compliance does not change when taxpayers know about the use of the taxes and even have control over the funds. Our results have important policy implications as the mere hypothetical possibility to express preferences on budget spending influences tax compliance.
\end{abstract}

\section{JEL Classification: H26, C91}

Keywords: tax evasion, tax compliance, tax knowledge, budget spending, real effort, experimental economics

\footnotetext{
- Department of Management, University of Paderborn, Warburger Str. 100, D-33098 Paderborn, Germany. Email: behnud.djawadi@wiwi.uni-paderborn.de, phone: +49-(0)5251-60-2093, fax: +49-(0)5251-60-3550

^ Corresponding author. Department of Management, University of Paderborn, Warburger Str. 100, D-33098 Paderborn, Germany.mail: rene.fahr@wiwi.uni-paderborn.de, phone: +49-(0)5251-60-2090, fax: +49-(0)525160-3550.
} 


\section{Introduction}

A legitimate interest of taxpaying citizens concerns the allocation of tax dollars to different funds and the way the government intends to spend the budget in general. It is therefore not surprising that Kirchler et al. (2008) claim that trust in authorities is a substantial determinant of tax compliance which can only be enforced partly by the legitimate power of tax authorities to audit tax files, impose and prosecute penalties on tax evaders. Empirical evidence suggests that educating taxpayers about the tax system (Vogel 1974, Song and Yarbrough 1978, Wartick 1994), tax laws (Eriksen and Fallan 1996, Palil and Mustapha 2011) and informing them about negative effects of tax evasion (Holler et al. 2008), sanctions and fines (Schwartz and Orleans 1967, Park and Hyun 2003) is a useful policy in order to enhance tax compliance.

The present study contributes to this literature by investigating how firstly tax knowledge about public expenditures and secondly taxpayers' influence on budget spending affects tax compliance. Local governments seem to be well aware that tax knowledge about public expenditures is of major importance. For instance, cities like Seattle, Redmond and Kennewick in Washington State address these issues by clearly illustrating the services provided by the city and the resources needed to assure accountability to the community through easy-to-understand Budget-in-Brief reports. The German Federal Government recently launched an interactive internet-based communication tool ${ }^{1}$ on annual tax revenues and expenditures to make the federal budget accessible to citizens in a more user-friendly way. Additionally, the city of Redmond (Washington State) proposes budgeting by priorities. This process is aimed to be transparent, open and approved by council, aligning the budget to citizen priorities with the objective to provide for services which meet the key goals of the community. In Los Angeles (California), the annual "Major's Budget Day" seeks to engage residents in community building, giving them the opportunity to jointly identify regional priorities and encourage input on a range of policy development matters. However, these cases lack evidence of being effective to increase tax compliance.

Field studies in Switzerland report higher tax compliance and tax morale in regions where citizens can actively vote for budget spending (Pommerehne and Weck-Hannemann 1996, Feld and Frey 2002, Torgler 2005). Experimental literature on the concept of voice pioneered by Alm et al. (1993) support the findings of the field studies. The authors conduct a public good experiment with groups of 5 where each subject individually receives income and then

\footnotetext{
${ }^{1}$ The tool can be retrieved under: "http://www.bundeshaushalt-info.de/startseite/" (in German language).
} 
decides how much to provide for the underlying public good. Contributions are much higher if subjects are able to vote for the public good that is funded by their taxes. Wahl et al. (2010) also argue that high contribution results when the public good, for which citizens vote, is congruent with their own preferences.

Our contribution differs from the studies described above in the following way: We set up a purely hypothetical tax system which consists of tax items that can be found in the budget plan of the 14 German federal ministries. From each federal ministry we incorporate the corresponding tax item with the highest allocated budget of the fiscal year 2009. The tax system is completely transparent as taxpayers receive information on all hypothetical public expenditures. Taxpayers are told that the hypothetical government spends all of the collected tax money for these items on an equal basis. We regard the transparency of the tax system as accomplished by unraveling information about budget spending as a signal of trust to the taxpayers. To the knowledge of the authors, this is the first study that investigates the impact of tax knowledge regarding concrete tax expenditures on tax compliance.

In addition to that, other than examining group decision-making on tax and budget issues by different voting procedures (e.g. majority rule) to assure higher compliance (Alm et al. 1993, Frey 1997, Alm et al. 1999, Walker et al. 2000, Feld and Tyran 2002, Tyran 2004, Wahl et al. 2010) we instead investigate how taxpayers behave if they can decide individually upon budget spending which comes closely to their own preferences. In this way, we augment the range to express voice within the political system of a representative democracy. Specifically, in our setting taxpayers pay their tax duty individually without prior communication or negotiating with others, thus, no voting procedures or potential influence from other group members are at place. This fiscal exchange between the government and the taxpayers goes beyond the situation of merely informing the taxpayers about the composition of the different tax funds, as the government explicitly spends money for public goods and services that are closely aligned to the individual taxpayer's preferences. By changing the power of authorities in a controlled way, the impact of tax knowledge and influence on budget spending can be systematically investigated in different tax regimes. Our experimental design follows the standards in the recent literature (Boylan and Sprinkle 2001, Alm et al. 2010, Heinemann and Kocher 2010). As a measure for increasing external validity, the entire experiment is explicitly framed in a tax context and taxpayers earn their money with real work. Further, to clearly identify the impact of tax knowledge and budget spending on tax compliance it is important to control for the individual perception of the power of and generally the overall orientation towards tax authorities. We measure the power of authorities by the participant's 
risk attitudes as they identify the threatening effect of audit probabilities and fines. By measuring the participant's motivational posture "tax commitment" using a scale suggested by Braithwaite (2003), we identify the individual's moral obligation in paying taxes in general and the overall orientation towards the tax authority. The study of Li et al. (2011) regarding the potential influence on budget spending is closest related to ours. They conduct an experiment to investigate the effect of donations to governmental institutions that are designated for specific purposes. In their setting, subjects receive an endowment of $20.00 \$$ and are free to decide on how much of this money they want to donate to a real organization differing in type (governmental agency vs. private charity), level (national, state, local) and fundable programs (Cancer Research, Disaster Relief, Education Enhancement, Parks and Wildlife). The authors show that donations to private charities are significantly higher than donations to governmental agencies; however, governmental agencies still receive on average donations of $22 \%$ of the endowment. Hence, the results suggest that citizens are willing to donate money to the government, especially if they can decide for which specific programs their donation is going to be used for. Yet, this study differs from ours in important dimensions as, firstly, donations are voluntary actions which are seen as a gift to the corresponding recipient whereas paying taxes is a civic obligation, and secondly, decisionmakers do not face any risk in losing money if they do not donate to the agencies which is different from tax matters, because tax authorities audit tax files with positive probability and impose penalties and fines if taxpayers do not truthfully report their tax liability.

In the next section we introduce our hypotheses. The experimental design and procedure is described in section 3. Our results are presented in section 4 and section 5 concludes.

\section{Tax Knowledge and Taxpayers' Influence on Budget Spending in Two Tax Systems}

We regard two tax systems, one with low and one with high power of authorities. The power of authorities is implemented by changing the audit probability to a low or a high rate. In each tax system, transparency in form of tax knowledge about public expenditures is provided, and, additionally, taxpayers are empowered to influence budget spending. In this manner, we are able to investigate how the degree of taxpayers' involvement in different tax regimes has to be tailored in order to have an effect on the taxpayers' behavior. When power is low, the practice of evading taxes becomes more attractive for taxpayers as authorities lack the resources to legitimately enforce compliance and, as such, the expected punishment is at a minimum. However, if taxpayers have the impression that tax authorities align the limited 
resources to community needs responsibly and strive to achieve community goals consistently, taxpayers will contribute their share by paying their taxes more dutifully. Especially when power is low higher compliance can only be achieved on this voluntary basis (Kirchler et al. 2008). Our first hypothesis is therefore:

H1: Tax compliance increases with the degree of taxpayers' involvement in form of tax knowledge and influence on budget spending in tax systems with low power of authorities.

Many studies found support for the effect of audit probabilities on tax compliance as suggested by the standard economic model of Allingham and Sandmo (1972) and have noted that an increase in audit rates leads taxpayers to report their taxable income more truthfully (see for example Spicer and Thomas 1982, Alm et al. 1992a, Alm et al. 1992b, Alm et al. 1995, Pommerehne and Weck-Hannemann 1996). Tax compliance can be legitimately enforced by tax authorities with high power, thereby diminishing the voluntary character of paying taxes and disposing taxpayers to meet their true tax liability. In tax systems with high power of authorities we therefore expect that compliance is already enforced on an elevated level by high audit rates so that enhancing taxpayers' involvement in these tax regimes will not result in even higher compliance, yielding:

H2: Tax compliance increases with the degree of enforcement exercised by tax authorities (irrespective of the degree of taxpayers' involvement in the tax system).

Further, to identify any effect of tax knowledge and influence on budget spending on tax compliance, it is important to disentangle those effects from 1) an overall positive orientation of the taxpayers towards the tax authority in general and from 2) tax compliance that is efficiently enforced by the tax authorities. An overall positive orientation towards the tax authority for example can be rooted in the belief that the tax system is desirable or that the tax authority has the legitimate power to impose taxes. In these cases, paying taxes is considered an inevitable citizens' duty resulting in high compliance. Enhancing taxpayers' involvement in different tax systems will therefore not result in even higher compliance, as taxable income is reported truthfully in any situation. On the contrary, if taxpayers have doubts about the intentions of tax authorities and do not feel as if they have been treated fairly or respectfully, an overall negative orientation towards tax authorities evolves which results in tax avoidance 
or tax evasion. To control for this, we measure taxpayers' orientation towards tax authorities by the motivational posture "tax commitment" (Braithwaite 2003) and come up with the following hypothesis:

H3: Tax compliance increases with the degree of an overall positive orientation towards the tax authority.

Lastly, as paying taxes is a decision under risk and uncertainty, the taxpayers' attitude towards risk is a further aspect which must be accounted for. A measure of the individual risk attitude is used to address the question how the threat of audits and fines by the tax authority is subjectively perceived. Referring to the traditional framework by Allingham and Sandmo (1972), a stronger perception of this threat adds more concavity to the taxpayer's utility function where the expected penalty might now outweigh the expected benefits of evading taxes, thus leading to higher tax compliance. To evaluate the perceived power of tax authorities we measure individual risk preferences by using a lottery in a multiple price list format as successfully employed by Holt and Laury (2002) and Goeree et al. (2003) and investigate in our last hypothesis:

H4: Tax compliance increases with the taxpayer's degree of risk aversion .

\section{Experimental Design and Procedure}

\section{Experimental Design}

We construct two hypothetical tax systems, one with high power and the other one with low power of authorities. We gradually increase the taxpayer's involvement in each of these two tax systems by employing three different treatments. Thus, our experiment follows a $2 \times 3$ design with 6 treatments in total.

Each treatment consists of two phases, only differing with respect to the second phase. In the first phase subjects individually work for their income in the slider task (Gill and Prowse 2012), see Figure A1 in Appendix A. As investigated in the experimental literature, legitimate assets produce rational behavior (Cherry et al. 2002). In the context of decisions under risk and uncertainty, earned income aligns decisions more closely to the participants' true preferences compared to endowed income (van Dijk et al. 2001, Gneezy 2003). The 
importance of effort and aspirations on tax evasion has also been shown in experimental settings by Boylan and Sprinkle (2001) and Kirchler et al. (2009).

For each slider that is correctly positioned by dragging the button of the slider with the computer-mouse from the starting position of 0 to the value of 50 a constant amount of the experimental currency "Taler" is added to the subject's current income. The working phase lasts for 120 seconds, followed by the second phase in which subjects state what amount from zero up to their earned income they want to declare for their tax report. In this phase we implement the treatments as follows: in the Knowledge treatment $(\mathrm{K})$ subjects are informed about all public tax expenditures of the hypothetical tax system. Specifically, subjects see a list of all tax items that constitute the hypothetical tax system on their computer screen and on the written instructions (see Figure A2 in Appendix A). Further, they are told that the hypothetical government will spend all the collected tax money equally on the hypothetical tax items. In the next treatment (BS), subjects can actively influence the budget spending. They receive exactly the same list of tax items but are allowed to decide on the item of expenditure to which their taxes should be allocated. Subjects are also free to choose more than one tax item or none of the tax items at all. The third treatment is the control treatment (Con) where subjects only report their taxable income and do not get any information about the tax system or the opportunity to decide on budget spending. Irrespective of the treatment, the tax report is audited in the tax system with high power of authorities with a preannounced probability of 0.25 and with an audit probability of 0.1 in the tax system with low power. In both tax systems, underreporting taxable income engenders a penalty amounting to the difference between the true and the declared income. In all treatments, the two phases are repeated three times. As soon as all decisions in the second phase have been made, the next period starts again with the working phase. Further, in order to avoid strategic behavior in subsequent periods as a response to previous audit outcomes, subjects learn about whether they have been detected in any period only after all three reports have been sent to the tax authority. Consequently, subjects learn about their payoffs for each period at the end of the experiment. This auditing procedure is communicated to all subjects before the start of the experiment and is therefore common knowledge.

\section{Experimental Procedure}

The experiment was conducted in May 2011 and January 2012 at the Business and Economic Research Laboratory (BaER-Lab) at the University of Paderborn and computerized using the software z-Tree (Fischbacher 2007). For each of the two tax systems with high and low audit 
probability we ran two sessions of the K, BS and Con treatments respectively. Subjects were recruited by the online recruiting system ORSEE (Greiner 2004) and were only allowed to participate in one session. In the tax system with low (high) audit probability 52 (56) subjects participated in the BS treatment, whereas 54 (55) subjects participated in the K and 54 (55) in the Con treatment respectively. After each subject was seated randomly to a computer workplace in a cubicle, each detached from one another, all subjects received the same introductory talk and were told not to communicate during the session. Instructions were then distributed and time for thorough reading was granted. After that, an example was given with numbers collected before the participants knew anything about the experiment, to make sure that everybody understood the rules of the game. In line with existing experimental studies in the tax literature, instructions were framed in a tax context (see for example Boylan and Sprinkle 2001 and Alm et al 2010), using terms like tax, tax authority, tax report, tax base etc. Prior to the first working phase, subjects practiced on the 48 sliders for 120 seconds to assure subjects are familiar with the slider task.

In the working phase, subjects earned their income by working on 48 sliders for 120 seconds and receiving 1500 Taler for each correctly positioned slider. Then, in the second phase, any fraction of this earned income could be declared as a tax base for the tax report. In both tax systems we set the tax rate to $30 \%$. If an underreported tax file was detected, the difference between the true value of the earned income and the income declared as the tax base was subtracted from the subject's earnings in this period. All rates and the audit probability were held constant across periods and across treatments within the same tax system. The tax items of the hypothetical tax system used in the K and BS treatment were taken from the federal budget across the 14 federal ministries in Germany and attached to the instructions. To be more specific, for each federal ministry, we identified the item with the highest tax expenditure in the fiscal year 2009, and placed this item with the exact wording on our tax list $^{2}$ (see Table A1 in Appendix A). This setting has two main advantages: Firstly, items are included that are found in reality, thus enhancing tax context, and secondly, as each federal ministry is represented exactly once, bias towards taxes for a particular purpose is minimized. The payoffs in each period were summed up and exchanged to Euro with a rate of 7500 Taler per Euro. On top of this, subjects received a show-up fee of $2.50 €$. After the final payoff was displayed at the end of the experiment, subjects were asked to answer a questionnaire which was divided into two parts. Whereas risk preferences were elicited using an incentivized ten-

\footnotetext{
${ }^{2}$ Two additional options "Other" and "Neutral" were available in case the subject was indifferent about the items listed.
} 
paired lottery choice framework in the first part, in an unpaid second part, tax commitment was measured with an eight item scale along with questions on the socio-economic background of the participants like age, gender etc. Each session lasted for about one hour and fifteen minutes and subjects earned $13 €$ on average.

Although there are no payoff spill-overs between the single periods and feedback about the period outcomes is given at the end of the experiment, the decisions of a subject might be driven by the same motivational postures. Therefore, we treat every subject as one independent observation, thus collecting in total 326 independent observations.

\section{Results}

We start by providing overall summary statistics. Then we present the results of nonparametric tests based on individual data to investigate whether knowledge about tax expenditures and taxpayer's influence on budget spending has an effect on tax compliance. For this, we compare the average compliance rate as the ratio of declared income in the taxreporting phase to the actual income earned in the working phase between the treatments within each tax system. Subsequently, robustness checks will be conducted by relating these results to further aspects discussed in the tax literature like the possible impact of income on tax compliance and the level of effort subjects exert during the slider task. Lastly, regression analysis is used to support the results.

\section{Summary Statistics}

From the 326 subjects who participated in one of the treatments, the major part studied economics and business administration. $47.24 \%$ of the subjects were male, $52.76 \%$ female. Subjects were on average 22.57 years old (sd.dev.:5.45). The major fraction of subjects had not filed a tax return in real life up to the point of the respective experiment. Across all treatments and tax systems, 61 subjects truthfully reported their taxable income in each period. 265 subjects reported at least once less taxable income and among them 18 subjects reported zero in every period.

Figure 1 shows the distribution of the tax items chosen during the BS treatments of both tax systems with high and low power of authorities. On average, subjects chose 4.5 tax items in each period when reporting their taxable income. The most prominent items with a choice frequency of well above 100 were mainly social services (Items 8 and 12), budget for 
regenerative energy (Item 7) and innovation/high-tech research (Item 6). As only a very tiny fraction of subjects chose no tax items at all (Item 16), the distribution clearly shows that subjects make strong use of the items offered to them, indicating the subjects' willingness to express preferences in the tax system.

Figure 1

Aggregated distribution of items chosen in the BS treatments of tax systems with low and high power of authorities

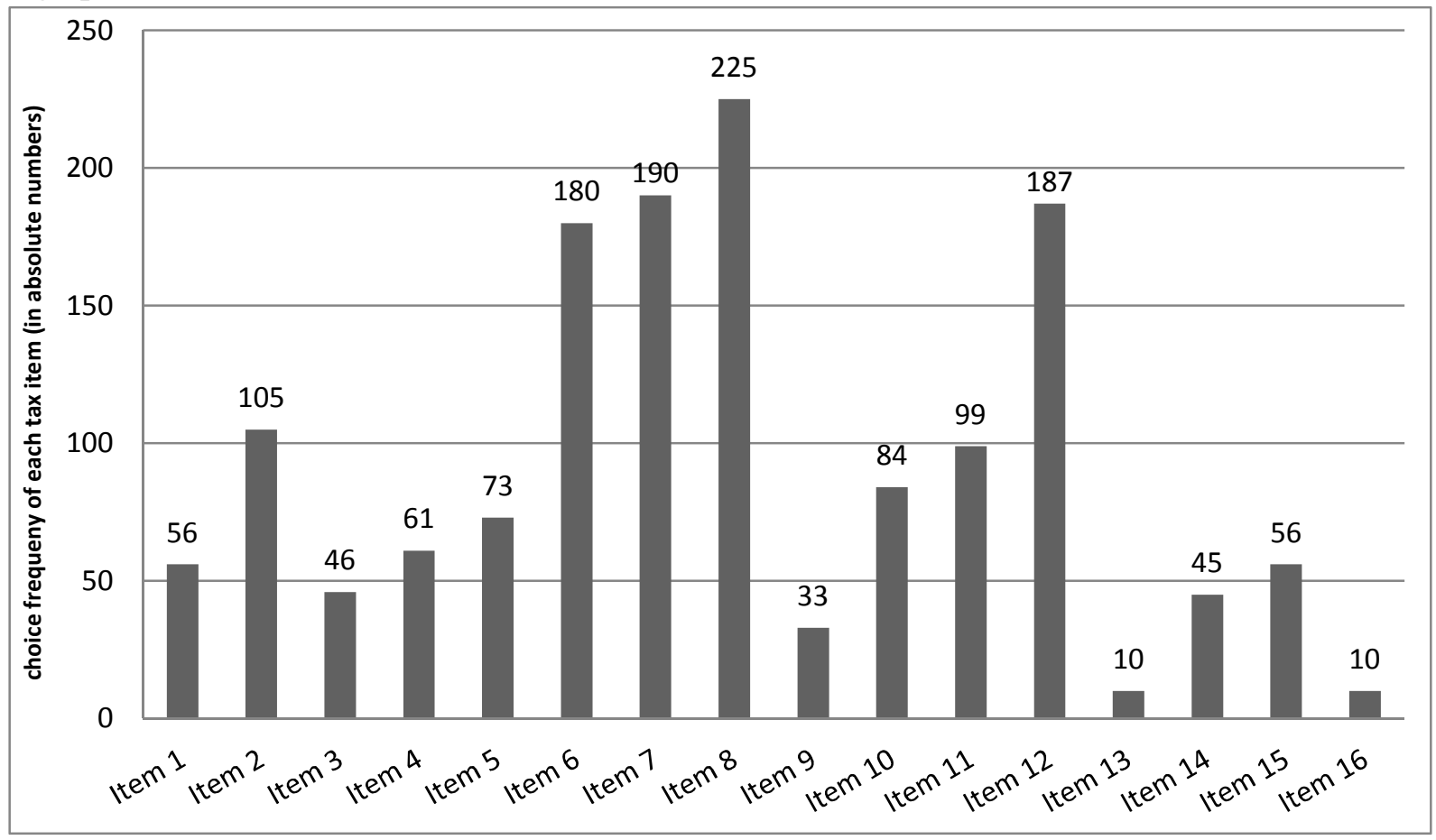

\begin{tabular}{|l|l|}
\hline Item 1 & Bilateral financial agreements \\
\hline Item 2 & Federal police \\
\hline Item 3 & Business administration of the German federal customs authority \\
\hline Item 4 & German patent office \\
\hline Item 5 & German federal railway \\
\hline Item 6 & Innovation and high-tech research \\
\hline Item 7 & Advancement for selective projects that make use of renewable energy \\
\hline Item 8 & State services for families \\
\hline Item 9 & Social insurance contributions and national assistance for soldiers \\
\hline Item 10 & Lump-sum reimbursement of the expenses of health insurances for services concerning the whole society \\
\hline Item 11 & Maintenance of the culture relationship with foreign countries \\
\hline Item 12 & Social Insurance \\
\hline Item 13 & Advancement for coal mining \\
\hline Item 14 & Governmental grant for farmers old-age insurance \\
\hline Item 15 & Other \\
\hline Item 16 & Neutral \\
\hline
\end{tabular}


Compliance Rate across Treatments within each Tax System (H1, H2)

Table 1 and Figure 2 show the average compliance rates for each treatment in the tax systems with low and high power of authorities respectively. Referring to compliance rates in the low power case we find strong evidence that on average subjects comply more in the BS treatment than in the Con treatment (Mann Whitney U-Test, $z=2.205, p=0.014$ ). This difference in compliance also holds between the $\mathrm{K}$ and the Con treatment, although this difference is only weakly significant (Mann Whitney U-Test, $\mathrm{z}=1.360, \mathrm{p}=0.087$ ). To evaluate the increasing effect of tax knowledge, and, on top of this, of the taxpayer's influence about budget spending on tax compliance, we apply a Jonckheere-Terpstra Test for ordered alternatives. We clearly reject the null hypothesis, stating that with a higher degree of taxpayer's involvement in the tax system there is no effect on compliance rates (Jonckheere-Terpstra, J-T value $($ standardized $)=2.185, \mathrm{p}=0.015)$. Thus, hypothesis $(\mathrm{H} 1)$, stating that tax compliance increases with the degree of taxpayer's involvement in form of tax knowledge and influence of budget spending with low power of authorities, is strongly supported.

Opposed to these results, in tax systems with high power of authorities we do not find any significant difference in compliance rates, neither between treatments BS and Con, nor between $\mathrm{K}$ and Con, where compliance rates in Con are even higher than in the $\mathrm{K}$ treatment (Mann Whitney U-Test, $\mathrm{z}=0.143, \mathrm{p}=0.444 ; \mathrm{z}=0.08, \mathrm{p}=0.938$ ). Also, we cannot reject the null hypothesis that compliance does not change with tax knowledge and the possibility for taxpayers to actively decide upon budget spending (Jonckheere-Terpstra, J-T value (standardized $)=0.110, \mathrm{p}=0.462)$. Thus, we can support our second hypothesis $(\mathrm{H} 2)$. High audit rates already enforce a high level of compliance, diminishing the effect of tax knowledge and influence on budget spending to statistically zero. Remarkably, although an increase in the audit probability raises tax compliance in each treatment in the tax system with high power of authorities compared to their equivalents in the low audit case, this difference is not significant for the $B S$ and $K$ treatments (Mann Whitney U-Test, $z=0.664, p=0.255$; $\mathrm{z}=0.30, \mathrm{p}=0.489$ ). Consistent with empirical findings, only in the Con treatment, where the usual tax reporting procedure takes place, higher audit probabilities cause tax compliance to rise significantly (Mann Whitney $\mathrm{U}-T e s t, \mathrm{z}=2.383, \mathrm{p}=0.008$ ). 
Table 1

Average compliance rate in each treatment and tax system (standard deviation in brackets)

\begin{tabular}{lcc}
\hline & $\begin{array}{c}\text { Tax system with low power } \\
\text { of authorities (audit probability: 0.1) }\end{array}$ & $\begin{array}{c}\text { Tax system with high power } \\
\text { of authorities (audit probability: 0.25) }\end{array}$ \\
\hline K & $0.672(0.33)$ & $0.688(0.30)$ \\
BS & $0.714(0.29)$ & $0.752(0.29)$ \\
Con & $0.539(0.40)$ & $0.742(0.31)$ \\
\hline
\end{tabular}

Figure 2

Average compliance rate across treatments and tax systems

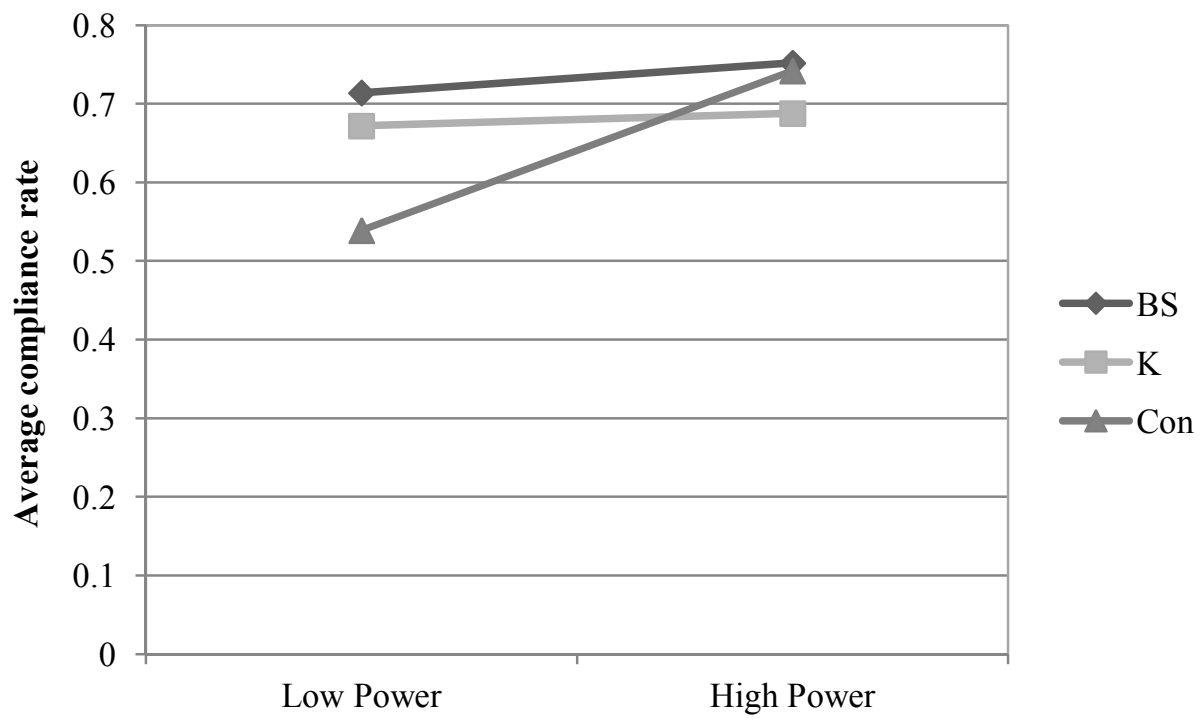

\section{Tax Commitment and Tax Compliance (H3)}

To control for the taxpayer's orientation towards tax authorities, we measure the motivational posture "tax commitment" by the eight statements suggested by Braithwaite (2003) and include these questions in a self-reporting questionnaire at the end of the experiment to avoid any manipulation of the decisions in the experiment (see for the eight statements Table A2 in the appendix). Respondents express their degree of agreement with the single statements on a scale from 1 (representing strong disagreement) to 5 (representing strong agreement). We follow Braithwaite and calculate for each subject a commitment index by adding up the rating for all eight statements and dividing it by the number of statements. ${ }^{3}$ With regards to our hypothesis $\mathrm{H} 3$ we would expect to find a positive correlation between commitment to the tax system and compliance. However, neither when considering all observations nor when inspecting treatments with low and high power of authorities separately do we find any

\footnotetext{
${ }^{3}$ One factor is suggested by applying the Kaiser's criterion. All our analyses are robust to replace the measured index by an index which weights each statement by its unrotated factor loading.
} 
evidence to reject the null hypothesis of no correlation between the commitment index and tax compliance (Spearman's rho (overall): 0.01, $\mathrm{p}=0.41$; Spearman's rho (low tax system):0.0978, $\mathrm{p}=0.11$; Spearman's rho (high tax system):0.007, $\mathrm{p}=0.46$ ). Using a Jonckheere-Terpstra Test to examine whether the commitment index is equally distributed across all treatments within the same tax system, we see that there is weak significant evidence that the commitment index differs in the treatments framed in the tax system with high power $($ Jonckheere-Terpstra, J-T value $($ standardized $)=1.788, \mathrm{p}=0.074)$. However, when looking at each of these treatments separately, commitment is not positively related to tax compliance in any of the treatments, implying that the decision with respect to compliance is independent of one's orientation towards the tax authorities (Spearman's rho (treatment BS): 0.0194, $\mathrm{p}=0.45$; Spearman's rho (treatment K): 0.11, p=0.22; Spearman's rho (treatment Con): $0.13, p=0.17$ ). The treatments in the tax system with the low detection rate do not differ significantly with regards to tax commitment (Jonckheere-Terpstra, J-T value (standardized) $=0.475, \mathrm{p}=0.635)$.

In summary, we interpret our findings in the way that the overall positive orientation towards tax authorities measured by the motivational posture "tax commitment" does not correlate with tax compliance, neither when we look at the overall sample nor in each single tax system. Therefore, we reject hypothesis H3 and infer that our results with respect to compliance cannot be ascribed to the subjects' orientation towards tax authorities.

\section{Risk Attitude and Tax Compliance (H4)}

We measure risk attitudes by using the binary lottery framework of Holt and Laury (2002). In this design subjects decide between two lotteries A and B, as shown in Table 2. Lottery A yields an outcome of $10 €$ with a probability $p$, and an outcome of $8 €$ with a probability (1-p). Accordingly, Lottery B provides an outcome of $19.25 €$ with the same probability $\mathrm{p}$ and $0.50 €$ with the probability (1-p). Regarding the differences in outcomes for each of the two lotteries we speak of lottery A as being "safer" than lottery B. The probability p increases across the decisions in steps of 0.1 so that obtaining the higher outcome in each lottery becomes more likely. Therefore, the expected payoffs change over the course of decisions, so it is assumed that risk neutral agents choose lottery A exactly four times before switching once and for all to lottery B. Similarly, switching before (after) that point indicates more riskseeking (more risk-averse) agents. The switching point thus defines a threshold $\mathrm{p}^{*}$ where the following holds: for $\mathrm{p}<\mathrm{p}^{*}$ lottery $\mathrm{A}$ and for $\mathrm{p}>\mathrm{p}^{*}$ lottery $\mathrm{B}$ is chosen. There is a range of 
possible values which $\mathrm{p}^{*}$ can take that satisfies the condition above, because $\mathrm{p}$ is not continuous but instead increases in discrete steps of 0.1 .

Table 2

Binary lottery framework to measure risk attitude

\begin{tabular}{|c|c|c|c|c|c|}
\hline \multirow[t]{2}{*}{ Round } & \multicolumn{2}{|l|}{ Lottery A } & \multicolumn{2}{|l|}{ Lottery B } & \multirow{2}{*}{$\begin{array}{l}\text { Expected payoff } \\
\text { difference* }\end{array}$} \\
\hline & $\mathrm{p}$ & $(1-p)$ & $\mathrm{P}$ & $(1-p)$ & \\
\hline 1) & 0.1 of $10 €$ & 0.9 of $8 €$ & 0.1 of $19.25 €$ & 0.9 of $0.50 €$ & $5.83 €$ \\
\hline 2) & 0.2 of $10 €$ & 0.8 of $8 €$ & 0.2 of $19.25 €$ & 0.8 of $0.50 €$ & $4.15 €$ \\
\hline 3) & 0.3 of $10 €$ & 0.7 of $8 €$ & 0.3 of $19.25 €$ & 0.7 of $0.50 €$ & $2.48 €$ \\
\hline 4) & 0.4 of $10 €$ & 0.6 of $8 €$ & 0.4 of $19.25 €$ & 0.6 of $0.50 €$ & $0.80 €$ \\
\hline 5) & 0.5 of $10 €$ & 0.5 of $8 €$ & 0.5 of $19.25 €$ & 0.5 of $0.50 €$ & $-0.88 €$ \\
\hline 6) & 0.6 of $10 €$ & 0.4 of $8 €$ & 0.6 of $19.25 €$ & 0.4 of $0.50 €$ & $-2.55 €$ \\
\hline 7) & 0.7 of $10 €$ & 0.3 of $8 €$ & 0.7 of $19.25 €$ & 0.3 of $0.50 €$ & $-4.23 €$ \\
\hline 8) & 0.8 of $10 €$ & 0.2 of $8 €$ & 0.8 of $19.25 €$ & 0.2 of $0.50 €$ & $-5.90 €$ \\
\hline 9) & 0.9 of $10 €$ & 0.1 of $8 €$ & 0.9 of $19.25 €$ & 0.1 of $0.50 €$ & $-7.58 €$ \\
\hline 10) & 1.0 of $10 €$ & 0.0 of $8 €$ & 1.0 of $19.25 €$ & 0.0 of $0.50 €$ & $-9.25 €$ \\
\hline
\end{tabular}

Note: *The difference in expected payoffs was not shown to subjects.

Following Holt and Laury (2002) and Goeree et al. (2003) we replace the notion of expected payoffs with expected utilities and use the utility function $U(x)=x^{1-r}$ where $\mathrm{x}$ is the monetary payoff from the lottery and $r$ a coefficient that represents the agent's constant relative risk aversion (CRRA). The individual risk preferences are then determined by calculating the curvature of the underlying utility function using the switching point in the lottery to estimate the coefficient. ${ }^{4}$

Subjects were asked to make their decisions for the lottery part after each session. Four subjects were afterwards selected at random to be paid for one randomly drawn row of the lottery table and the received outcome was added to the subject's present earnings. Table 3 shows the decision lines of the lottery framework where subjects switched once from lottery A to lottery B. Overall, 32 subjects who switched more than once between the lotteries were excluded from the analysis, as their choice pattern indicated no clear crossover.

\footnotetext{
${ }^{4}$ Details on the derivation of the individual risk preferences can be found in appendix B.
} 
Table 3

Switching points of the subjects in the lottery framework

\begin{tabular}{|c|c|c|c|c|c|c|c|}
\hline \multirow[b]{2}{*}{$\begin{array}{l}\text { Switching Point } \\
\text { from Lottery A } \\
\text { to Lottery B }\end{array}$} & \multicolumn{3}{|c|}{ High Power } & \multicolumn{3}{|c|}{ Low Power } & \multirow[t]{2}{*}{ Tota } \\
\hline & $\mathrm{K}$ & $\mathrm{BS}$ & Con & $\mathrm{K}$ & BS & Con & \\
\hline Line 1 & 1 & - & - & - & - & - & 1 \\
\hline Line 2 & - & - & - & - & - & - & - \\
\hline Line 3 & 3 & - & - & 1 & 1 & - & 5 \\
\hline Line 4 & 3 & 2 & 4 & 2 & 3 & 6 & 20 \\
\hline Line 5 & 5 & 16 & 6 & 10 & 8 & 8 & 53 \\
\hline Line 6 & 14 & 4 & 7 & 6 & 6 & 5 & 42 \\
\hline Line 7 & 8 & 6 & 11 & 7 & 12 & 6 & 50 \\
\hline Line 8 & 9 & 8 & 12 & 9 & 11 & 15 & 64 \\
\hline Line 9 & 1 & 6 & 6 & 4 & 8 & 5 & 30 \\
\hline Line 10 & 1 & 2 & 2 & - & 1 & 2 & 8 \\
\hline Never Switched & 4 & 6 & 2 & 2 & - & 2 & 16 \\
\hline Total & 49 & 50 & 50 & 41 & 50 & 49 & 289 \\
\hline
\end{tabular}

Notes: K: Knowledge treatment, BS: Budget Spending treatment, Con: Control treatment.

To analyze the impact of risk preferences on the decisions in the tax experiment we sort the subjects into four risk types ranging from risk loving (category 1) to risk averse (category 4). Subjects with a switching point earlier than decision line five are grouped into category 1 , subjects switching in decision line 5 from lottery A to lottery B are assigned to category 2 which represents the risk neutral type. Subjects who switch in decision line 6 are classified as being slightly risk averse (category 3 ) and finally subjects having a switching point beyond decision line 6 are characterized as being risk averse (category 4). 5 subjects who started with Lottery B in decision line 1 and switched once to lottery A in decision line 4 were classified as being risk loving and therefore grouped in category 1 . Table 4 shows the corresponding distribution of our sorting procedure.

Table 4

Distribution of risk categories

\begin{tabular}{lll}
\hline Risk category & \# of subjects & r-coefficient \\
\hline Risk loving & $31(11 \%)$ & -0.382 \\
Risk neutral & $53(18 \%)$ & 0.014 \\
Slightly risk averse & $42(14 \%)$ & 0.282 \\
Risk averse & $168(57 \%)$ & 0.898 \\
\hline
\end{tabular}


Applying maximum likelihood analysis to the binary lottery choices, we capture the degree of risk aversion for each risk category by estimating the $r$ coefficient via the switching point (see Table 4). ${ }^{5}$ The r-values are consistent with the literature, as the coefficient increases with higher risk aversion, obtaining a value smaller than 0 for the risk loving type and a value close to one for the risk averse type (Holt and Laury 2002, Goeree et al. 2003). Also notice that the r-value of each risk category falls exactly in intervals that were used in the literature to match subjects successfully with their corresponding risk attitude, so we have strong support that our sorting procedure is correct. Turning to hypothesis $\mathrm{H} 4$, we find for the overall sample as well as for each single tax system that compliance rises significantly with greater risk aversion (Jonckheere-Terpstra, (overall) J-T (standardized) $=2.942, \mathrm{p}=0.0016$; (tax system with low power of authorities) J-T (standardized) $=2.04, \mathrm{p}=0.02$; $($ tax system with high power of authorities) J-T (standardized) $=2.38, \mathrm{p}=0.0086$ ), thus, we find strong support for H4. Figure 3 shows the results graphically. If we reconsider our previous results about the effect of tax knowledge and taxpayer's control over the different tax items on the observed compliance rates in both tax systems, we have to check that within each tax system the risk groups are similarly distributed across the single treatments. Looking at the risk distribution in each single tax system, we do not find any evidence that a certain risk group is more present in one treatment compared to the other (Jonckheere-Terpstra, (tax system with high power of authorities) J-T (standardized) $=0.464, \mathrm{p}=0.639$; (tax system with low power of authorities) J$\mathrm{T}($ standardized $)=1.430, \mathrm{p}=0.153)$. Hence, as our treatments in both tax systems are similar with respect to risk profiles, we have strong support that in the tax system with low power of authorities higher compliance is indeed due to the concepts of tax knowledge and the influence on budget spending, while in the tax system with high power of authorities the elevated power of authorities outshines any effect associated with these two concepts by taking compliance through high audit rates already to a high level.

\footnotetext{
${ }^{5}$ Detailed results on the $\mathrm{r}$-coefficients and compliance rates across all treatments and risk categories can be found in Table B.1 of Appendix B.
} 
Figure 3

Compliance rates across all risk categories

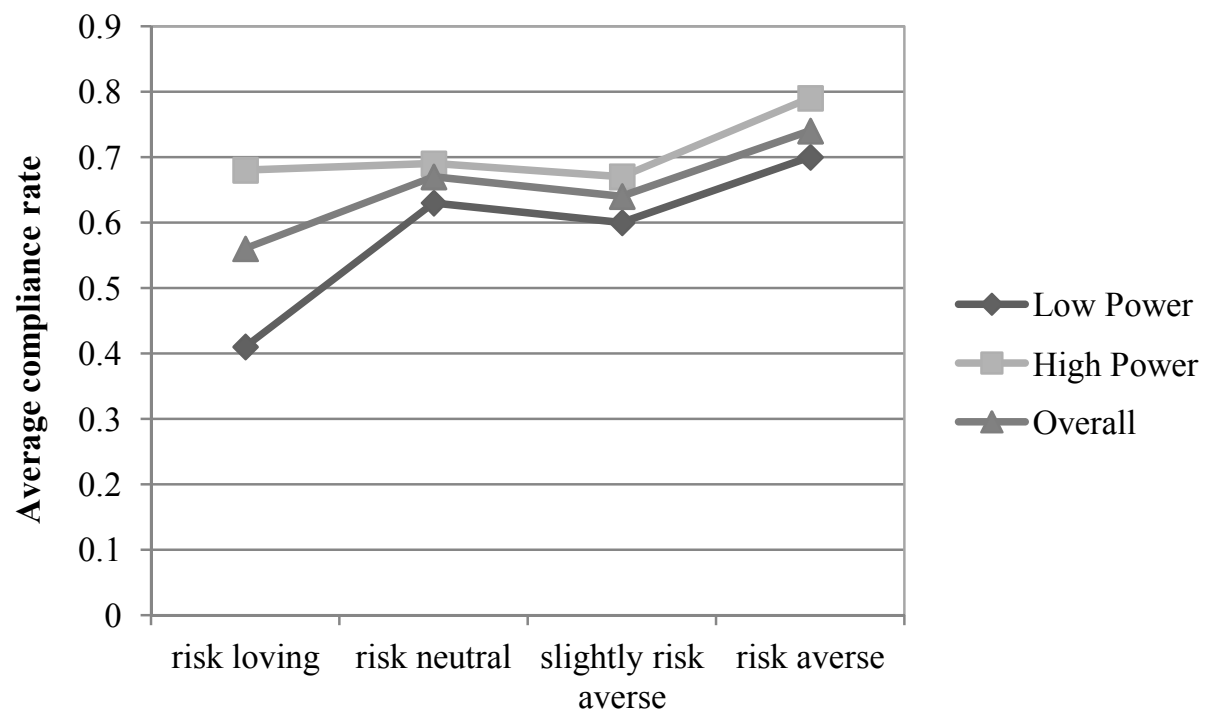

\section{Robustness of the Results}

Following part of the recent literature, we require subjects to earn their income by performing the slider task before declaring their taxable income rather than just being endowed by the experimenter. From a methodological point of view it is therefore of interest to investigate whether this exerted effort somehow influences the decision in the tax reporting phase. For instance in the experimental study by Boylan and Sprinkle (2001), tax compliance rises significantly when subjects have to work for their taxable income instead of just being endowed with money from the experimenter. Kirchler et al. (2009) found evidence that when subjects exert high effort on a task, the earned income is not put at risk that easily, leading to less tax evasion. Varying performance in the slider task might lead to different income levels. Therefore we reflect on our previous results and investigate whether income and level of exerted effort affect the subjects' behavior in any way.

\section{Income and Tax Compliance}

To investigate whether the compliance pattern in our experiment is associated to a certain type of income level, we define three income groups (Low, Average, High). Subjects who earned on average equal or less than 97,500 Taler in the slider task were assigned to the low group, those who earned between 97,500 Taler and 114,000 were put in the average group, and lastly the high group consisted of subjects earning more than 114,000 Taler. Figure 4 shows the average compliance rates in the three different income groups for each treatment 
and tax system. Analyzing the complete dataset across all tax systems and treatments, we do not find any evidence that income is somehow related to tax compliance (JonckheereTerpstra, J-T value (standardized) $=1.000, \mathrm{p}=0.317$ ). This result holds also for each tax system (Jonckheere-Terpstra, J-T value (standardized) $=0.901, \mathrm{p}=0.367 ; \mathrm{J}-\mathrm{T}$ value (standardized $)=0.887, \mathrm{p}=0.375)$, and we find no support for a significant relationship between income and compliance either in any of the single treatments. Thus, we conclude that income is not related to compliance by any means in our experiment.

\section{Exerted Effort and Tax Compliance}

We test the potential impact of effort on tax compliance by using the difference in subjects' incomes as a measure of change in exerted effort for each pair of periods. If there is a significant increase in income from one period to the other, we assume that relatively more effort was exerted to achieve this higher income level, and, the other way around, we assume relatively lower effort exerted if income decreased from one period to the other.

Table 5 shows the average income earned in each period overall and separated for each tax system. When comparing all the paid periods pair-wise in the overall dataset and for each tax system individually, we find that the level of income increases significantly from the former to the later period, indicating that relatively more effort was always exerted from the previous to the subsequent period. However, using the non-parametric Wilcoxon-Test for matched groups, we observe only in one case (tax system with low power of authorities, period 1 vs. period 3) a significant change in compliance, in all other cases we do not find any support which speaks for a relationship between effort and compliance, neither overall nor in each single tax system (Table 6). Therefore, we can infer that, in our experiment, exerted effort on the task and tax compliance are not related to each other. 
Figure 4

Average compliances rate across different income groups and different treatments in the tax systems with high and low power of authorities (EI=Earned Income)
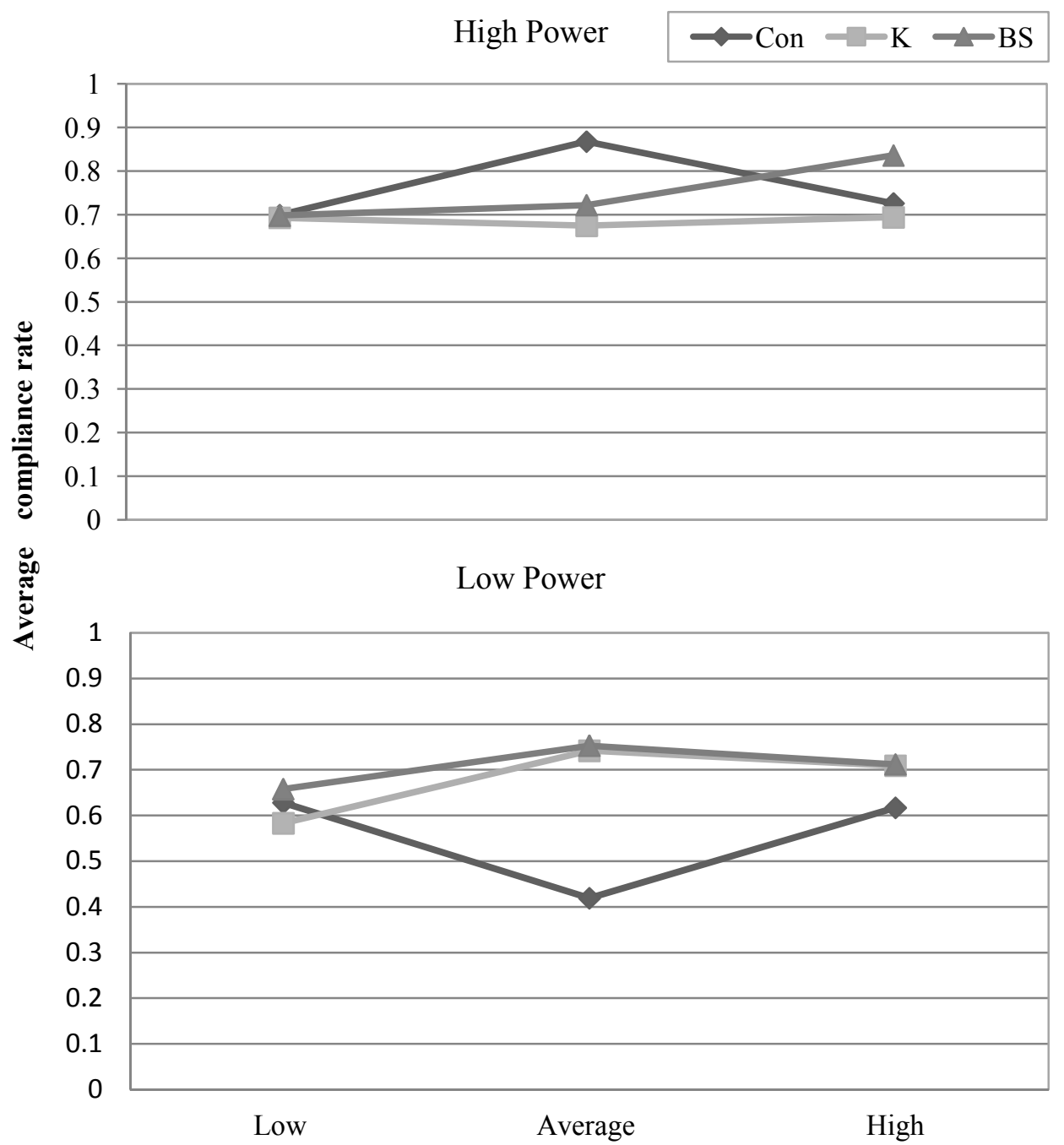

$\mathrm{EI}<=97500 \quad 97500<\mathrm{EI}<=114000 \quad$ EI $>114000$

Notes: K: Knowledge treatment, BS: Budget Spending treatment, Con: Control treatment 
Table 5

Average income earned in each period (in experimental currency Taler, standard deviation in brackets)

\begin{tabular}{llll}
\hline & Period 1 & Period 2 & Period 3 \\
\hline Overall & $33782.21(8384.06)$ & $35291.41(8578.29)$ & $36349.69(8621.38)$ \\
Tax system with low power & $35062.50(7172.57)$ & $36309.38(7165.36)$ & $37293.75(7308.86)$ \\
Tax system with high power & $32548.19(9260.57)$ & $34310.24(9669.31)$ & $35439.76(9655.55)$ \\
\hline
\end{tabular}

Table 6

Average change in compliance between all possible pairs of periods (z-statistics of non-parametric Wilcoxon Test for matched groups and p-values in brackets)

\begin{tabular}{llll}
\hline & Period 1 vs. Period 2 & Period 1 vs. Period 3 & Period 2 vs. Period 3 \\
\hline Overall & -0.01 & -0.0076 & 0.029 \\
& $(0.75, \mathrm{p}=0.45)$ & $(1.22, \mathrm{p}=0.22)$ & $(0.16, \mathrm{p}=0.87)$ \\
Tax system with low power & 0.03 & -0.037 & -0.004 \\
& $(1.55, \mathrm{p}=0.12)$ & $(1.98, \mathrm{p}=0.04)$ & $(-0.47, \mathrm{p}=0.63)$ \\
Tax system with high power & -0.01 & 0.02 & 0.0097 \\
& $(-0.50, \mathrm{p}=0.61)$ & $(-0.29, \mathrm{p}=0.77)$ & $(0.67, \mathrm{p}=0.50)$ \\
\hline
\end{tabular}

\section{Regression Analysis}

A multivariate analysis will help to check the robustness of the non-parametric analysis and will allow considering the potential influence of further determinants on tax compliance not discussed in the previous analysis so far. Firstly, as a benchmark we use a standard OLS model, with the average compliance rate as dependent variable. As shown in Table 7, the first specification in column (1) contains variables to revisit the predictions of the first two hypotheses. These variables include the level of the taxpayer's involvement (the experimental treatments Knowledge, Budget spending and Control) and the power of authorities (Low versus High). We use Knowledge, Budget spending and Low as dummy variables, thus omitting the variables Control and High. We add subject characteristics such as age, gender and whether subjects have filed a tax form in reality before (Tax experience). We also control for income that was totally earned over the three periods by the numbers of sliders that were positioned correctly. We interact the level of taxpayer's involvement and the power of authorities to capture the effect of tax knowledge and budget spending on tax compliance (Low*Knowledge, Low*Budget spending). Column (2) controls for the subjects' orientation towards tax authorities by using the individual commitment index derived from the subjects' 
responses to the motivational posture statements. Finally, Column (3) incorporates the individual risk preferences by adding dummy variables for the risk types risk neutral, slightly risk averse and risk averse. The risk type "risk loving" serves as reference category.

Table 7

Average Compliance Rate (OLS Model, robust standard errors)

\section{(1)}

(2)

(3)

Dependent Variable

Average Compliance Rate

\begin{tabular}{|c|c|c|c|}
\hline Knowledge & $-0.046(0.057)$ & $-0.049(0.057)$ & $-0.058(0.058)$ \\
\hline Budget spending & $0.004(0.057)$ & $-0.003(0.056)$ & $-0.025(0.056)$ \\
\hline Low & $-0.195 * * *(0.069)$ & $-0.251 * * *(0.076)$ & $-0.252 * * *(0.077)$ \\
\hline Income (total) & $0.006(0.005)$ & $0.006(0.005)$ & $0.002(0.005)$ \\
\hline Age & $0.006 * *(0.003)$ & $0.006 * *(0.003)$ & $0.007 * *(0.003)$ \\
\hline Female & $0.031(0.370)$ & $0.040(0.038)$ & $0.046(0.038)$ \\
\hline Tax experience & $0.049(0.038)$ & $0.047(0.039)$ & $0.035(0.040)$ \\
\hline Low * Knowledge & $0.181 * *(0.091)$ & $0.191 * *(0.090)$ & $0.211 * *(0.094)$ \\
\hline Low* Budget spending & $0.174 *(0.089)$ & $0.186 * *(0.087)$ & $0.188 * *(0.088)$ \\
\hline Commitment & & $0.022(0.016)$ & $0.014(0.016)$ \\
\hline Risk neutral & & & $0.058(0.074)$ \\
\hline Slightly risk-averse & & & $0.033(0.078)$ \\
\hline Risk-averse & & & $0.153 * *(0.060)$ \\
\hline Constant & $0.484 * * *(0.116)$ & $0.412 * * *(0.128)$ & $0.392 * * *(0.133)$ \\
\hline $\mathrm{R}$ squared & 0.067 & 0.074 & 0.105 \\
\hline Observations & 326 & 326 & 294 \\
\hline Number of subjects & 326 & 326 & 294 \\
\hline
\end{tabular}

Notes: Dependent variable is the average compliance rate. Robust standard errors are in parentheses. Reference groups are Control, High and Risk loving

* $\quad$ Significant at the $10 \%$ level.

** $\quad$ Significant at the $5 \%$ level.

*** $\quad$ Significant at the $1 \%$ level.

The results in Table 7 are robust across specifications and consistent with the previous analysis. Taxpayer's involvement in form of tax knowledge and deciding on budget spending increases compliance by $18.1 \%$ and $17.4 \%$ respectively in the tax system with low power of authorities, compared to the corresponding control treatment. When controlling for the subjects' orientation towards tax authorities and risk attitude, the compliance rate is found to rise even more in the tax knowledge and budget spending treatments. In all specifications, neither knowing about the use of taxes nor influence on budget spending affects compliance in the tax system with high power of authorities. Overall, low power of authorities leads to significantly less compliance compared to the counterpart tax system with high power of 
authorities. Taking these results together we find additional support for our hypotheses H1 and H2. The subjects' orientation towards tax authorities has no effect on compliance, but risk attitude does influence compliance, as risk-averse subjects report significantly more taxable income than risk-loving subjects. Income, gender and tax experience do not influence compliant behavior. Age has a positive impact on compliance in each specification, however the effect is rather small.

For robustness considerations, we specify an alternative model. Based upon our experimental design, the data constitute a panel as each subject makes a decision in each period. Further, because no feedback between periods is given, we employ pooled OLS regressions, with the single individual compliance rate per period as dependant variable. The explanatory variables remain as in the benchmark, except for income that is now measured by the number of sliders correctly positioned per single period.

Table 8

Compliance rate per period (Pooled OLS Model, standard errors clustered over subjects)

\section{(1)}

(2)

(3)

Dependent Variable

\section{Compliance Rate per period}

\begin{tabular}{|c|c|c|c|}
\hline Knowledge & $-0.044(0.057)$ & $-0.048(0.057)$ & $-0.056(0.057)$ \\
\hline Budget spending & $0.003(0.056)$ & $-0.004(0.056)$ & $-0.025(0.055)$ \\
\hline Low & $-0.196^{* * *}(0.068)$ & $-0.253^{* * *}(0.075)$ & $-0.25^{* * *}(0.076)$ \\
\hline Income (per Period) & $0.022 *(0.013)$ & $0.022 *(0.013)$ & $0.014(0.012)$ \\
\hline Age & $0.006^{* *}(0.003)$ & $0.006 * *(0.003)$ & $0.007 * *(0.003)$ \\
\hline Female & $0.034(0.037)$ & $0.043(0.038)$ & $0.049(0.038)$ \\
\hline Tax experience & $0.049(0.038)$ & $0.047(0.038)$ & $0.035(0.039)$ \\
\hline Low * Knowledge & $0.180 * *(0.090)$ & $0.190 * *(0.089)$ & $0.209 * *(0.093)$ \\
\hline Low* Budget spending & $0.174 * *(0.088)$ & $0.186 * *(0.086)$ & $0.187 * *(0.087)$ \\
\hline Commitment & & $0.022(0.015)$ & $0.014(0.156)$ \\
\hline Risk neutral & & & $0.057(0.073)$ \\
\hline Slightly risk-averse & & & $0.033(0.077)$ \\
\hline Risk-averse & & & $0.152 * *(0.059)$ \\
\hline Constant & $0.458 * * *(0.109)$ & $0.386^{* * * *(0.122)}$ & $0.359 * * *(0.127)$ \\
\hline R squared & 0.053 & 0.059 & 0.082 \\
\hline Observations & 978 & 978 & 882 \\
\hline Number of subjects & 326 & 326 & 294 \\
\hline $\begin{array}{ll}\text { Notes: } & \begin{array}{l}\text { Dependent variable } \\
\text { and Risk loving. } \\
\text { * }\end{array} \\
\text { Significant at the 1c }\end{array}$ & & & groups are Con, High, \\
\hline Significant at the $5^{\circ}$ & & & \\
\hline *** & & & \\
\hline
\end{tabular}


As shown in Table 8, the results stay qualitatively the same compared to the benchmark and almost do not vary in quantitative terms either. Only two exceptions are noticeable. The increase in compliance by influencing budget spending in the tax system with low power of authorities is also in the first specification significant at the 5\% level. The other exception concerns the income earned in each period. In the first two specifications there is a significantly positive effect on compliance. However, after we control for subjects' orientation towards tax authorities along with risk attitude this statistical significance disappears.

\section{Discussion and Conclusion}

In the present paper, we examine the potential impact of tax knowledge about public expenditures and taxpayers' influence to prioritize budget spending on tax compliance. Embedded in two hypothetical tax systems with high and low power of authorities respectively, we investigate in which specific tax system this transparency of the tax system and taxpayers' control over the use of the taxes is of major relevance. To clearly disentangle any effect from factors that are known to influence tax compliance from previous studies, we control for tax commitment, risk attitude, income and effort exerted on the task in the experiment. Tax compliance is higher in tax systems with low power of authorities when providing complete transparency about public expenditures and when taxpayers are given the possibility to decide on the use of their taxes. With a powerful tax authority in place which is reflected in high audit rates, this tax knowledge and the influence on budget spending do not affect compliance rates. Further, we controlled for other potential determinants of tax compliance. By measuring the overall orientation towards tax authorities through the motivational posture "tax commitment", we made sure that observed compliance rates are not driven by orientations which are disproportionally in favor of or opposed to tax authorities or general attitudes towards paying taxes. We find that "tax commitment" and tax compliance are not related to each other, and thus, do not explain our results. As we determined the subjects' risk attitudes as a measure of the perceived power of authorities, we found evidence that compliance increases with the degree of risk aversion. However, all treatments in both tax systems with low and high power of authorities display similar risk profiles so that our main results are not affected by an uneven distribution of risk, biasing compliance in a particular direction. Factors like income or the level of effort which was exerted to perform the task are not related to compliance in any way. Our results have important policy implications as 
obviously the mere hypothetical possibility of expressing preferences concerning budget spending influences tax compliance. Tax authorities can provide taxpayers with information along with the annual tax declaration about the different tax items, the volume of the federal budget and a feedback mechanism to express preferences about the allocation of their tax dollars. This is a realizable avenue for tax authorities to increase the transparency of the tax system and to shape budget goals by gauging how citizens value public services. Providing information on the use of taxes for citizens through designated websites, as in the case of the Federal budget in Germany, or collecting information on citizens' preferences as demonstrated by local governments in Washington State, is therefore a promising way to increase tax compliance and is in particular much easier to implement than increasing direct democracy by letting the citizens vote on specific tax funds.

However, the fact that the study is conducted in the laboratory with students as subjects provides reasons for caution. As described in the analysis, the major fraction of subjects had no experience in filing a tax return and the overall size of the monetary compensation was relatively limited compared to the annual salary of the average taxpayer. Thus, the decision to allocate small stakes on tax items might be different from reactions of someone who regularly works for money and receives a much higher annual income. Additionally, the tax items in the experiment were of hypothetical nature which sets limits towards generalizing our findings. Further research needs to investigate the robustness of our results with different mechanisms to reveal citizen service preferences in a more heterogeneous and diverse population. Still, our findings mark an important starting point for creating an effective way of increasing tax compliance in controlled experiments. The involvement of stakeholders in strategic business decisions has successfully been proven to increase the commitment of stakeholders to organizations in many studies. In a similar vein, the taxpayer-involvement fuels tax compliance when governmental control is far from being perfect. 


\section{Acknowledgements}

We are grateful to the University of Paderborn for providing funds to finance the experiments. We thank Mark Baukmann, Tim Harrenkamp, Nico Kirwald, Christoph Rolfes and Matthias Rüther for able research assistance in programming the experimental software and running the sessions as well as helpful discussions when designing the experiment. We thank the seminar participants of the International Conference "Shadow Economy - Tax Evasion and Money Laundering" held 2011 in Münster, the " $1{ }^{\text {st }}$ FAU Workshop on Tax Compliance" held 2012 in Nuremberg, the " $11^{\text {th }}$ Journées Louis-André Gérard-Varet" held 2012 in Marseille and the "Economic Science Association European Conference 2012" in Cologne, in particular Thiess Büttner, Erich Kirchler, Marco Maffezzoli, Stefan Muehlbacher and Matthias Wibral for valuable comments.

\section{References}

Alm, J., Cherry, T., Jones, M., McKee, M., 2010. Taxpayer Information Assistance Services and Tax Compliance Behavior. J. Econ. Psychol., 31, 577-586.

Alm, J., Jackson, B. R., McKee, M., 1992a. Estimating the Determinants of Taxpayer Compliance with Experimental Data. Natl. Tax J., 45, 107-114.

Alm, J., Jackson, B. R., McKee, M., 1993. Fiscal exchange, collective decision institutions, and tax compliance. J. Econ. Behav. Organ., 22, 285-303.

Alm, J., McClelland, G. H., Schulze, W. D., 1992b. Why do people pay taxes? J. Public Econ., 48, 21-38.

Alm, J., McClelland, G. H., Schulze, W. D., 1999. Changing the Social Norm of Tax Compliance by Voting. Kyklos, 52, 141-171.

Alm, J., Sanchez, I., de Juan, A., 1995. Economic and noneconomic factors in tax compliance. Kyklos, 48, 3-18.

Allingham, M. G., Sandmo, A., 1972. Income Tax Evasion: A Theoretical Analysis. J. Public Econ., 1, 323-338.

Boylan, S. J., Sprinkle, G. B., 2001. Experimental evidence on the relation between tax rates and compliance: The effect of earned vs. endowed income. J. Am. Tax Assoc., 23, 75-90.

Braithwaite, V., 2003. Dancing with Tax Authorities: Motivational Postures and Noncompliant Actions. Taxing Democracy: Understanding Tax Avoidance and Evasion, 15-40. 
Cherry, T.L., Frykblom, P., Shogren, J.F., 2002. Hardnose the Dicator. Am. Econ. Rev., 92, 1218-1221.

Eriksen, K., Fallan, L., 1996. Tax knowledge and attitudes towards taxation; A report on a quasi-experiment. J. Econ. Psychol., 17, 387-402.

Feld, L. P., Frey, B. S., 2002. Trust breeds trust: How taxpayers are treated. Econ. Gov., 3, 87-99.

Feld, L. P., Tyran, J-R., 2002. Tax Evasion and Voting: An Experimental Analysis. Kyklos, $55,197-222$.

Fischbacher, U., 2007. z-Tree: Zurich Toolbox for Ready-made Economic Experiment. Exp. Econ.,10, 171-178.

Frey, B. S., 1997. A Constitution for Knaves Crowds out Civic Virtues. Econ. J., 107, 10431053.

Gill, D. , Prowse, V., 2012. A structural analysis of disappointment aversion in a real effort competition. Am. Econ. Rev., 102, 469-503.

Gneezy, U., 2003. Do high wages lead to high profits? An experimental study of reciprocity using real effort. Working Paper, The University of Chicago GSB, Chicago.

Goeree, J.K., Holt, C.A., Palfrey, T.R., 2003. Risk Averse behavior in generalized matching pennies games. Game. Econ. Behav., 45, 97-113.

Greiner, B., 2004. An Online Recruiting System for Economic Experiments, in: Kurt Kremer, Volker Macho (Eds.): Forschung und wissenschaftliches Rechnen 2003. GWDG Bericht 63, Goettingen: Ges. für Wiss. Datenverarbeitung, pp.79-93.

Heinemann, F., Kocher, M. G., 2010. Tax Compliance Under Tax Regime Changes. ZEW Discussion Paper No. 10-020.

Holler, M., Hoelzl, E., Kirchler, E., Leder, S., Mannetti, L., 2008. Framing of information on the use of public finances, regulatory fit of recipients and tax compliance. J. Econ. Psychol., 29, 597-611.

Holt, C., Laury, S., 2002. Risk Aversion and Incentive Effects. Am. Econ. Rev., 92, 16441655.

Kirchler, E., Hoelzl, E., Wahl, I., 2008. Enforced versus voluntary tax compliance: The "slippery slope" framework. J. Econ. Psychol., 29, 210-225.

Kirchler, E., Muehlbacher, S., Hoelzl, E., Webley, P., 2009. Effort and Aspirations in Tax Evasion: Experimental Evidence. J. Appl. Psychol., 58, 488-507.

Li, S.X, Eckel, C.C., Grossman, P.J., Brown, T.L., 2011. Giving to government: Voluntary taxation in the lab. J. Public Econ., 95, 1190-1201. 
Palil, M.R., Mustapha, A.F., 2011. Determinants of Tax Compliance in Asia: A case of Malaysia. Eur. J. Soc. Sci., 24, 7-32.

Park, C. G., Hyun, J. K., 2003. Examining the determinants of tax compliance by experimental data: A case of Korea. J. Policy Model., 25, 673-684.

Pommerehne, W. W., Weck-Hannemann, H., 1996. Tax rates, tax administration and income tax evasion in Switzerland. Public Choice, 88, 161-170.

Schwartz, R., Orleans, S., 1967. On legal sanctions. U. Chicago Law Rev., 34, 274-300.

Song, Y.D., Yarbrough, T.E., 1978. Tax ethics and taxpayer attitudes: A survey. Public Admin. Rev., 38, 442-452.

Spicer, M.W., Thomas, J. E., 1982. Audit probabilities and tax evasion decision: an experimental approach. J. Econ. Psychol., 2, 241-245.

Torgler, B., 2005. Tax morale and direct democracy. Eur. J. Polit. Econ., 21, 525-531.

Tyran, J.-R., 2004. Voting when money and morals conflict: an experimental test of expressive voting. J. Public Econ., 88, 1645-1664.

van Dijk, F., Sonnemans, J., van Winden, F., 2001. Incentive systems in a real effort experiment. Eur. Econ. Rev., 45, 187-214.

Vogel, J., 1974. Taxation and public opinion in Sweden: An interpretation of recent survey data. Natl. Tax J., 27, 499-513.

Wahl, I., Muehlbacher S., Kirchler, E., 2010. The impact of voting on tax payments. Kyklos, $63,144-158$.

Walker, J.M., Gardner, R., Herr, A., Ostrom, E., 2000. Collective Choice in the commons. Experimental results on proposed allocation rules and votes. Econ. J., 110, 212234.

Wartick, M.L., 1994. Legislative Justification and the Perceived Fairness of Tax Law Changes: A Referent Cognitions Theory Approach. J. Am. Tax. Assoc., 16, 106123. 


\section{Appendix}

\section{A. Supplementary material of experiment}

Table A. 1

List of options used in the K and the BS treatment (items were in German and sorted alphabetically)

\begin{tabular}{|c|c|}
\hline Item 1 & Bilateral financial agreements \\
\hline Item 2 & Federal police \\
\hline Item 3 & Business administration of the German federal customs authority \\
\hline Item 4 & German patent office \\
\hline Item 5 & German federal railway \\
\hline Item 6 & Innovation and high-tech research \\
\hline Item 7 & $\begin{array}{l}\text { Advancement for selective projects that make use of renewable } \\
\text { energy }\end{array}$ \\
\hline Item 8 & State services for families \\
\hline Item 9 & Social insurance contributions and national assistance for soldiers \\
\hline Item 10 & $\begin{array}{l}\text { Lump-sum reimbursement of the expenses of health insurances for } \\
\text { services concerning the whole society }\end{array}$ \\
\hline Item 11 & Maintenance of the culture relationship with foreign countries \\
\hline Item 12 & Social Insurance \\
\hline Item 13 & Advancement for coal mining \\
\hline Item 14 & Governmental grant for farmers ${ }^{6}$ old-age insurance \\
\hline Item 15 & Other \\
\hline Item 16 & Neutral \\
\hline
\end{tabular}

Table A.2

Braithwaite's statements (2003) representing commitment to tax system

\begin{tabular}{|ll|}
\hline 1. & Paying tax is the right thing to do. \\
\hline 2. & $\begin{array}{l}\text { Paying tax is a responsibility that should be willingly accepted by all } \\
\text { Australians [all Australians replaced by: the whole society] }\end{array}$ \\
\hline 3. & I feel a moral obligation to pay my tax. \\
\hline 4. & Paying my tax ultimately advantages everyone. \\
\hline 5. & I think of tax paying as helping the government do worthwhile things. \\
\hline 6. & Overall, I pay my tax with good will. \\
\hline 7. & I resent paying tax. \\
\hline 8. & I accept responsibility for paying my fair share of tax. \\
\hline
\end{tabular}


Figure A.1

Screen displaying the slider task

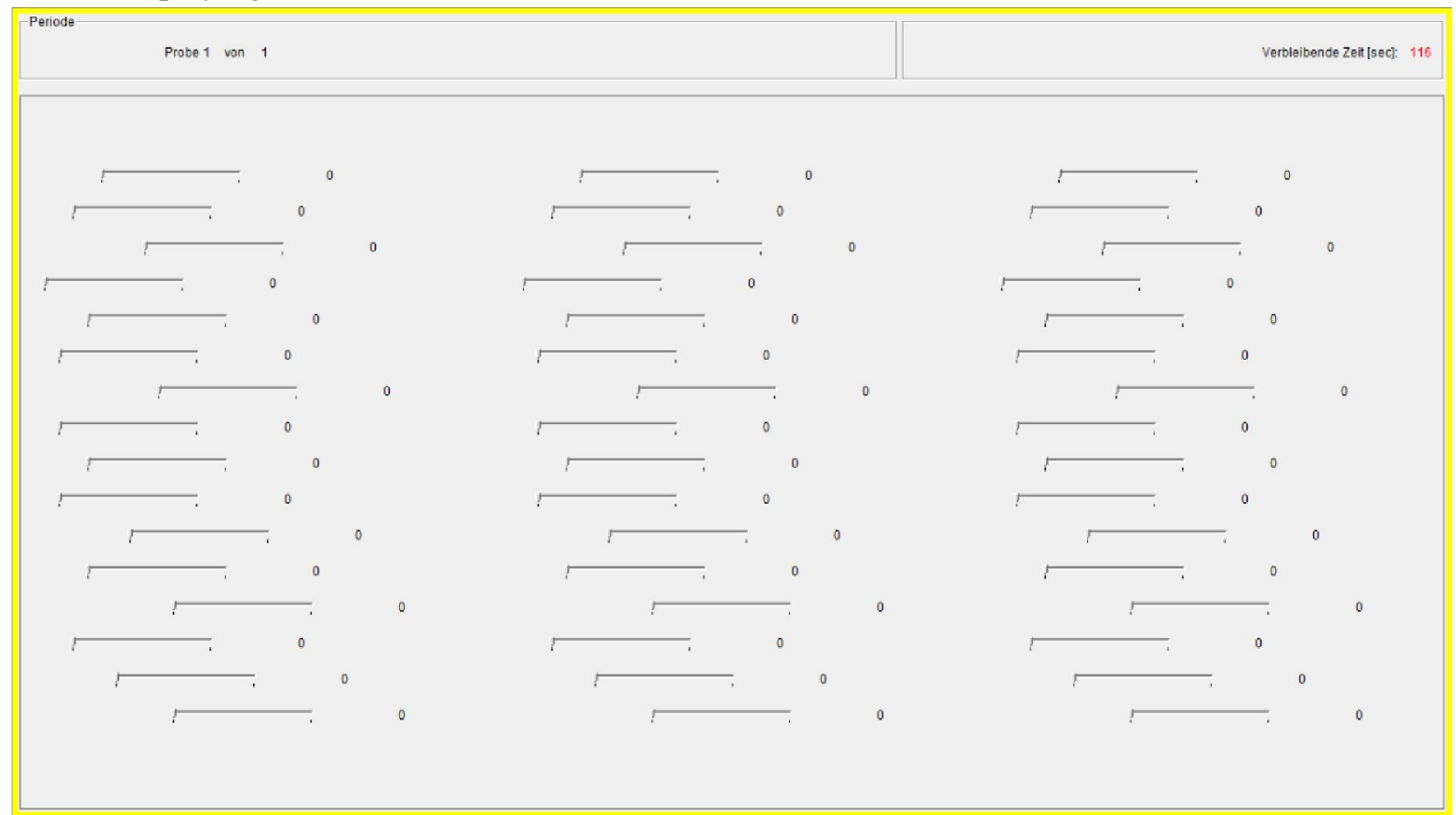

In every working phase subjects saw 48 sliders and had 120 seconds time to position as many of them correctly. For each correctly positioned slider on the value of 50 a certain amount was added to the subject's income. 
Figure A.2

Split-screen in the tax-reporting phase

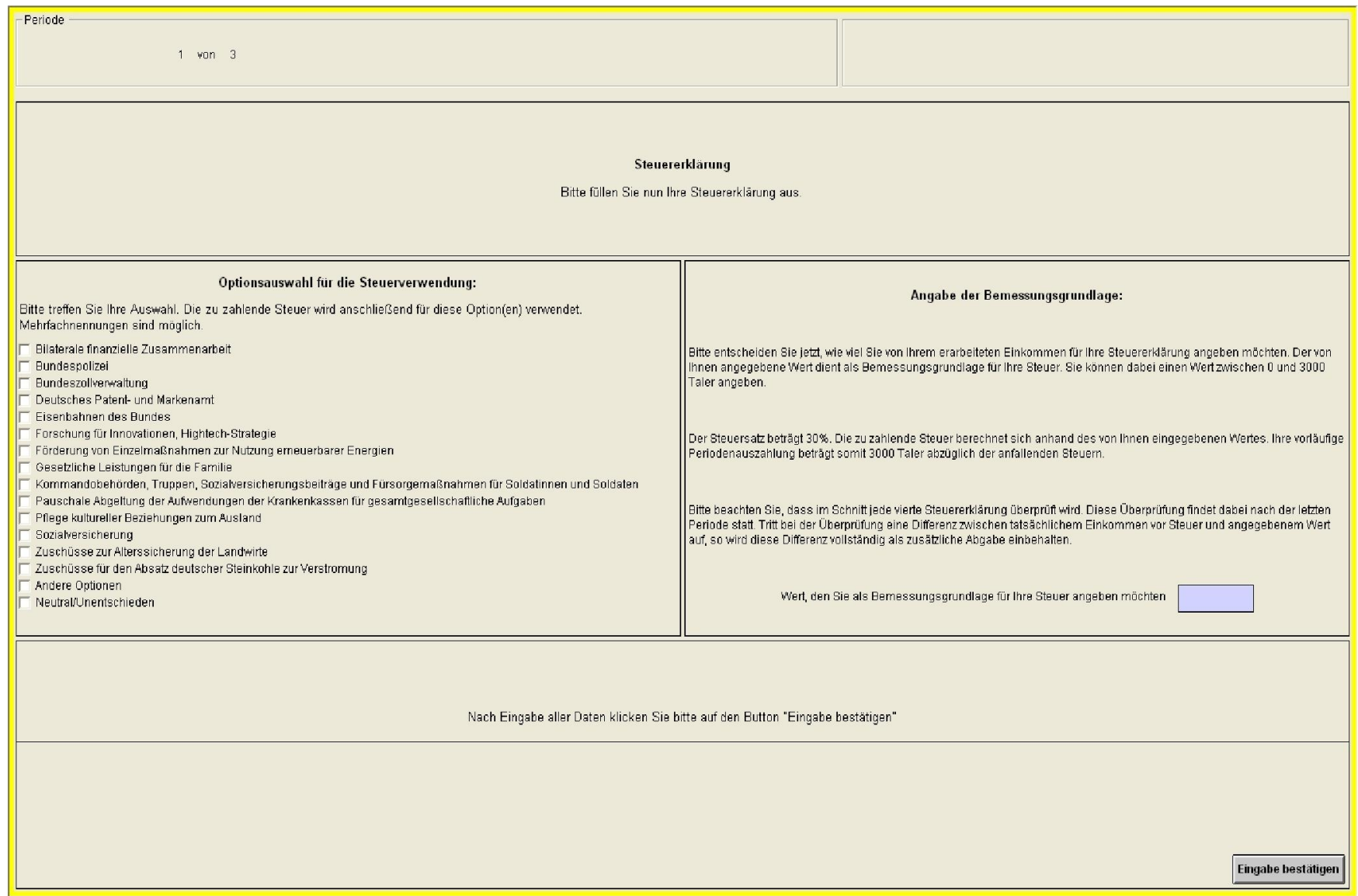

On the left-hand side of the screen the list of tax items were shown where choosing more than one item was possible. In the $\mathrm{K}$ treatment this list was shown without the possibility of choosing specific tax items. On the right-hand side subjects were asked to state what amount of their income they want do declare for the tax report. 


\section{B. Derivation of individual risk preferences}

As shown in Goeree et al. (2003) when using a utility function with relative constant risk aversion the threshold $\mathrm{p}^{*}$ can be rewritten as a function of $\mathrm{r}$ :

$$
\begin{aligned}
& p^{*}(r)=U(8)-U(0.50) / U(19.25)-U(0.50)+U(8)-U(10) \\
& p^{*}(r)=8^{1-r}-0.50^{1-r} / 19.25^{1-r}-0.50^{1-r}+8^{1-r}-10^{1-r}
\end{aligned}
$$

Assuming that subjects may do mistakes when deciding upon a binary choice we allow for noise in the existing model and introduce a probabilistic choice function that was first developed by Luce (1959) and was shown to approximate the choice behavior in the lottery quiet well (see for example Holt/Laury 2002 and Goeree et al. 2003). This continuous, steady increasing function takes the shape of a logistic function and gives for each alternative with its associated expected utility the probability that subjects will decide for that alternative. With higher associated expected utility the probability rises that this alternative will be chosen among others. With respect to our setup the probability of choosing lottery A over B thus can be expressed with the following probabilistic choice function:

$$
\begin{aligned}
& p_{A}=\exp \left(U_{A} / \mu\right) / \exp \left(U_{A} / \mu\right)+\exp \left(U_{B} / \mu\right) \\
& p_{A}=1 / 1+\exp \left(\left(U_{B}-U_{A}\right) / \mu\right)
\end{aligned}
$$

The denominator ensures that each probability lies between 0 and 1 . The parameter $\mu$ expresses the noise in the decision-making process that arises due to insensitivity in payoff differences. For example, as $\mu$ goes to zero, $\mathrm{A}$ is chosen with probability 1 if it yields a higher expected utility over $\mathrm{B}$, in the opposite case, when $\mu$ goes to infinity the decision becomes completely random as the expected utilities from $\mathrm{A}$ and $\mathrm{B}$ are perceived to be equal. In line with Holt/Laury (2002) and Goeree et al (2003) we normalize our utility function to avoid scaling effects on $\mu$. By specifying $U$ in terms of $U(x)=x^{1-r}-0.50^{1-r} / 19.25^{1-r}-0.50^{1-r}$ the utility for all possible outcomes from the lottery is bounded between 0 and 1 , where the worst possible outcome of $0.50 €$ provide the lowest utility of zero and the best possible outcome of $19.25 €$ the highest utility of 1 . With this new specification the probability of choosing A over B can now be expressed as followed:

$p_{A}=1 / 1+\exp \left(\left(p-p \cdot 10^{1-r}-(1-p) \cdot 8^{1-r}\right) / \mu\right)$

Using maximum likelihood estimation we are able to derive the $r$ coefficient and the noise parameter out of the binary choices made by all subjects in our experiment. 
Table B.1

Risk categories, $r$-coefficients and average compliance rates for each treatment and tax system (number of subjects in brackets)

\begin{tabular}{|c|c|c|c|c|c|c|c|c|c|c|}
\hline \multirow[b]{2}{*}{ Risk categories } & \multicolumn{4}{|c|}{ Tax system with high power of authorities } & \multicolumn{4}{|c|}{ Tax system with low power of authorities } & \multirow[b]{2}{*}{$\begin{array}{l}\text { overall } \\
\text { compliance } \\
\text { rate }\end{array}$} & \multirow[b]{2}{*}{ r-coefficient } \\
\hline & $\mathrm{BS}$ & $\mathrm{K}$ & Con & $\begin{array}{l}\text { compliance rate } \\
\text { for each risk } \\
\text { category }\end{array}$ & $\mathrm{BS}$ & $\mathrm{K}$ & Con & $\begin{array}{l}\text { compliance } \\
\text { rate for each } \\
\text { risk } \\
\text { category }\end{array}$ & & \\
\hline risk loving & $0.70(4)$ & $0.62(9)$ & $0.83(4)$ & $0.68(17)$ & $0.51(4)$ & $0.62(4)$ & $0.20(6)$ & $0.41(14)$ & $0.56(31)$ & -0.382 \\
\hline risk neutral & $0.74(16)$ & $0.64(5)$ & $0.61(6)$ & $0.69(27)$ & $0.75(8)$ & $0.71(10)$ & $0.44(8)$ & $0.63(26)$ & $0.67(53)$ & 0.014 \\
\hline slightly risk averse & $0.62(4)$ & $0.68(14)$ & $0.66(7)$ & $0.67(25)$ & $0.63(6)$ & $0.66(6)$ & $0.48(5)$ & $0.60(17)$ & $0.64(42)$ & 0.282 \\
\hline risk averse & $0.79(28)$ & $0.74(23)$ & $0.83(33)$ & $0.79(84)$ & $0.73(32)$ & $0.70(22)$ & $0.66(30)$ & $0.70(84)$ & $0.74(168)$ & 0.898 \\
\hline overall compliance rate & $0.75(52)$ & $0.69(51)$ & $0.78(50)$ & & $0.71(50)$ & $0.69(42)$ & $0.55(49)$ & & & \\
\hline r-coefficient & 0.622 & 0.457 & 0.584 & & 0.518 & 0.474 & 0.548 & & & \\
\hline
\end{tabular}




\section{Instructions ${ }^{6}$ (Original instructions were in German)}

- For the course of the experiment, all amounts of money will be stated in the fictitious currency "Taler".

- The experiment consists of three periods.

- Your payment is in no stage of the experiment dependent on the decisions of the other participants.

- The payoff of one period does not affect the payoff of any other period.

- Before the first period starts, a test run will take place.

- This test run does not influence your payoff; it should only help you to understand the experiment.

- At the end of the experiment you will be asked to fill out a questionnaire which consists of two parts. For this you will get a short set of instructions as soon as the experiment has ended. The answers in this questionnaire do not influence your payoff which you will receive from this experiment.

- The participants act completely independently and do not interact with each other. All decisions are private and are not accessible to other participants at any stage of the experiment.

\section{Procedure of a Period}

\section{Phase 1}

- This phase lasts 120 seconds.

- In this phase you must work on a task which consists of placing little sliders in the middle, exactly on the target position 50, with the computer mouse (see illustration). The order of positioning the sliders is not relevant. Only the amount of correctly placed sliders counts.

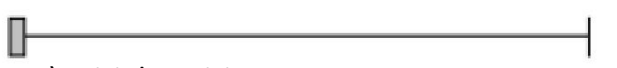

a) Initial position

\section{0}

- For each correctly positioned slider you will be rewarded 1500 Talers.

- After the 120 seconds are over, you will be informed about the amount of correctly placed sliders as well as the amount of Talers earned.

- These Talers represent your income.

\section{Phase 2}

- There is a tax which arises in each period. You will be thus asked to fill out a tax report in phase 2 . The tax rate amounts to $30 \%$ of the declared income.

\footnotetext{
${ }^{6}$ Please note: Sentences marked with \{\} belong to the $\mathrm{K}$ treatment and sentences marked with $*\{\}^{*}$ belong to the BS treatment only
} 
- In your tax return you can decide how much of your earned income you would like to declare. This declared income is the basis of assessment for your tax payment (tax base). You can declare an amount between 0 Talers and your entire earned income.

\begin{tabular}{|ll|}
\hline Your income before taxes & $=$ amount of correctly positioned sliders $\mathrm{x} 1500$ Talers \\
Tax base & $=$ declared income between 0 Talers and entire earned income \\
Paid tax & $=$ tax base $\mathrm{x} 0.3$ \\
Your income after taxes & $=$ your income before taxes - paid tax \\
Payment of the period & $=$ your income after taxes \\
\hline
\end{tabular}

- * Please imagine you have the possibility to choose the specific items for which the taxes are then used for. There are 16 options - multiple choices are possible.

- Please find the different options of use in the enclosed table.

- Please assume that the paid taxes are afterwards used for this/ these option(s). $\}^{*}$

- $\quad$ You will be informed about the specific use of your paid taxes.

- Please find the different possibilities of use in the enclosed table.

- Please assume that the paid taxes are only used for exactly these tax items.\}

- The tax return of every [forth] tenth person will be randomly audited.

- In case your tax return is checked and your tax base does not correspond with your income before taxes, a fine will be due in form of a supplementary as well as an additional payment.

- This additional charge equates to the difference between your income before taxes and your tax base, so that in consequence the amount of not declared income will be collected/ fined.

First Case:

If tax base $=$ income before taxes

$=>$ Payment of the period as above

Second Case:

If tax base $<$ income before taxes

Not declared income

Additional charge (consists of a

$=$ your income before taxes - tax base

supplementary and an additional payment)

Your income after taxes

with the additional charge

Payment of the period

$=$ not declared income

$=$ your income after taxes - additional charge $=$ your income after taxes with the additional charge

- Please be aware that the auditing of the tax files takes place at the end of the experiment. You will then be informed whether or not your tax return was checked in the respective period. 
- Consequently, you will first find out your payoffs from the three periods once the experiment has finished.

\section{Payments:}

- At the end of the experiment, your payoff will be exchanged at an exchange rate of 1 Euro per 7500 Talers. A show-up fee of 2.50 Euro is added to this amount which is then directly paid out to you in cash.

\section{Please note:}

- During the entire experiment, no form of communication is permitted.

- All mobile phones must be switched off during the complete duration of the experiment.

- The decisions you make within this experiment are anonymous, i.e. none of the other participants learns about the identity of a person who has made a specific decision.

- The payments are also handled anonymously. No other participant finds out how much money other participants have earned.

- Please remain seated until the end of the experiment. You will be called forward for your payoff through your seat number.

Good luck and thank you for your participation in this experiment! 


\section{Instructions Questionnaire}

- The experiment is now finished.

\section{Instructions for the questionnaire part 1:}

- In part 1 of this questionnaire, we would like to know how you would decide between "lottery A" and "lottery B".

- You will be shown the following screen with two choices:

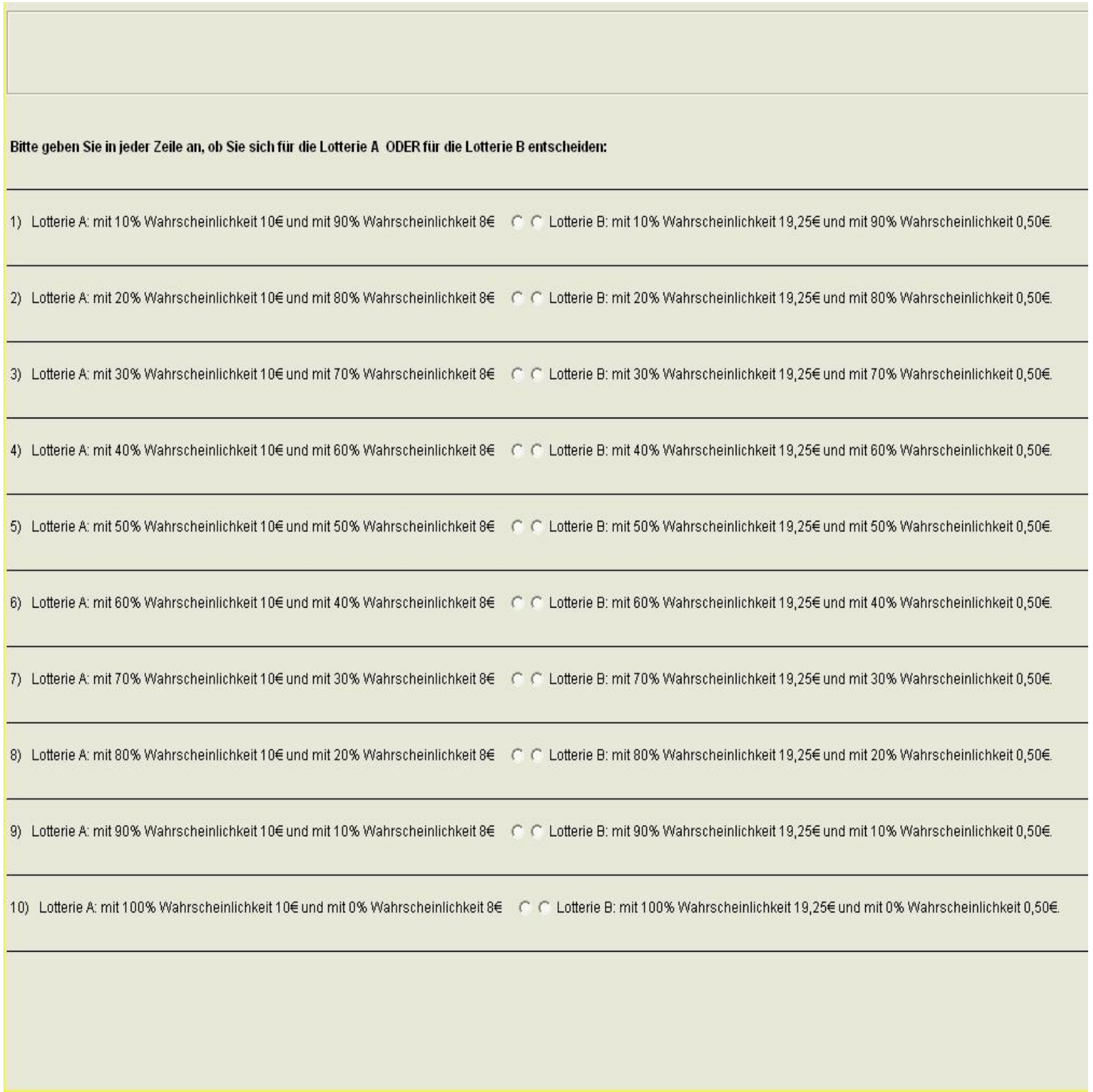

- Please make a decision between lottery A and lottery B for every row (numbered 1 to 10). Please tick the left box, if you have chosen lottery $\mathbf{A}$, and the right box, if you have chosen lottery $B$. 


\section{Further opportunity to win in part 1 of the questionnaire}

- In this part of the questionnaire, you once again have the chance to earn money.

- Every $7^{\text {th }}$ participant wins, so four participants are drawn.

- Four cabin numbers are drawn out of a box.

- The four participants with the drawn cabin numbers play for the additional payment before they receive their payment from the first experiment and once they have finished the second part of this questionnaire.

- Should you be one of the four drawn participants, you will play for the additional payment using a 10 -sided die.

- With your first throw of the 10-sided die, the row which then matters for the payment is determined. With your second throw, you then play the lottery you chose in the respective row.

Example: Supposing you rolled a 3 with your first throw, you then play the lottery which you chose in the third row.

- If you rolled a number between 1 and 3 and

○ chose lottery A, you then win 10 EUR.

○ chose lottery B, you then win 19.25 EUR.

- If you rolled a number between 4 and 10 and

O chose lottery A, you then win 8 EUR.

○ chose lottery B, you then win 0.50 EUR.

The second part of this questionnaire follows, once all participants have answered the first part of the questionnaire. The answers of the second part are not relevant to payment.

Please note again that the questions are analyzed anonymously and that communication is not permitted during the entire experiment.

Thank you very much for your participation in this experiment! 